\title{
Cryptococcus gattii FUNGEMIA: REPORT OF A CASE WITH LUNG AND BRAIN LESIONS MIMICKING RADIOLOGICAL FEATURES OF MALIGNANCY
}

\author{
Flávio de Mattos OLIVEIRA(1,2), Cecília Bittencourt SEVERO(1,2), Luciana Silva GUAZZELLI(1,2) \& Luiz Carlos SEVERO(3,4)
}

\begin{abstract}
SUMMARY
A 64-year-old apparently immunocompetent white man developed lung and brain lesions of disseminated cryptococcosis. The radiologic features mimicked those of lung cancer metastatic to the central nervous system. C. gattii was recovered from cultures of bronchoalveolar lavage fluid, brain biopsy, and blood. The same fungus was recovered from pulmonary and brain specimens at autopsy. Serum and cerebrospinal fluid cryptococcal antigen tests were diagnostic in our case and should be included in the diagnostic evaluation of unexplained pulmonary and cerebral lesions. A literature search showed few reports of fungemia by this species of Cryptococcus, contrasting to C. neoformans.
\end{abstract}

KEYWORDS: Fungemia; Cryptococcosis; Cryptococcus gattii.

\section{INTRODUCTION}

Cryptococcus gattii differs from the closely related yeast $C$. neoformans in phenotypic characters, natural habitat, epidemiology, clinical manifestation of disease and response to antifungal therapy. C. gattii unlike C. neoformans, is considered to be a primary fungal pathogen because virtually always affects apparently immunocompetent hosts, human and animal ${ }^{8,9}$.

We describe a case of Cryptococcus gattii infection in a patient without evidence of immunosuppression (including HIV infection) with fungemia, an unusual manifestation of this species of Cryptococcus, in whom lung and brain lesions of disseminated cryptococcosis mimicked bronchogenic carcinoma with brain metastases.

\section{CASE REPORT}

A 64-year-old apparently immunocompentent white man was admitted to the hospital complaining of fever, weakness, anorexia, headache, dyspnea, cough, purulent sputum production, and disorientation (one week duration). It was noted that he had lost $20 \mathrm{~kg}$ in weigh during the previous three months. He had smoked one pack of cigarettes daily for the past 50 years. One year prior to admission arterial hypertension was found. On physical examination he was a thin man who was confused and mumbling. The temperature was $39^{\circ} \mathrm{C}$, the pulse was 90 , and the respirations were 27 . The blood pressure was 140/90 mmHg. The patient had a stiff neck, positive Lasegue's, and Kerning's signs. Bilateral Brudzinski signs were present. Ophthalmologic examination revealed pupils non reactive and bilateral papilledema. Chest roentgenogram revealed overinflation of both lungs and a spherical mass lesion, $5 \mathrm{~cm}$ in diameter, in the superior segment of the right lower lobe (Fig. 1). Contrast-enhanced axial cranial computed tomographic (CT) scan showed nonenhancing cystic large mass within the right temporal lobe, hydrocephalus (Fig. 2) and multiple nodules through the brain parenchyma. Dexametazone, $4 \mathrm{mg}$ IV 6/6 hr, was begun, and the patient was transferred to an intensive care unit. He underwent fiberoptic bronchoscopy with bronchoalveolar lavage. The bronchial specimens obtained were centrifuged at $700 \mathrm{rpm}$ for 15 minutes. The sediment was smeared onto glass slides. The preparations were allowed to air dry and them stained with May-Grunwald Giemsa (MGG) solution. Procedure: The air-dried slides were fixed in absolute methanol for five minutes and incubated in $2 \%$ MGG solution in distilled water for 15 minutes at room temperature. After rinsing in tap water the slides were air dried in a vertical position. Microscopic examination of bronchial washings and brushings revealed numerous narrow-based budding, encapsulated yeasts (Fig. 3). Sabouraud's dextrose agar (SDA) plus chloramphenicol showed cream-colored mucoid colonies. The culture hydrolysed urea and produced melaninlike pigments in the presence of Guizotia abyssinica agar (Staib agar). The canavanine-glycine-bromothymol agar coloured by blue indicated $C$. gattii. The brain temporal mass was aspirated under stereotactic CT guidance. The mucopurulent liquid obtained was microscopically evaluated. Acid-fast organisms, bacterial, and malignant cells were not seen in the smears with special stains, but abundant encapsulated cells morphologically consistent with Cryptococcus were identified, and grew $C$. gattii. Bacterial cultures were negative. Lumbar puncture revealed clear cerebrospinal fluid (CSF) with a protein concentration of $105 \mathrm{mg} / \mathrm{dL}$ and glucose of $51 \mathrm{mg} / \mathrm{dL}$, while in blood glucose was $143 \mathrm{mg} / \mathrm{dL}$. There were 16 erythrocytes and two white cells

(1) Programa de Pós-Graduação em Pneumologia - Mestrado e Doutorado, Universidade Federal do Rio Grande do Sul.

(2) Laboratório de Micologia, Hospital Santa Rita, Santa Casa-Complexo Hospitalar, Porto Alegre, RS, Brasil.

(3) Departamento de Medicina Interna, Universidade Federal do Rio Grande do Sul, Porto Alegre, RS, Brasil.

(4) Pesquisador 1C do CNPq.

Correspondence to: L.C. Severo, Laboratório de Micologia/Hospital Santa Rita, Santa Casa-Complexo Hospitalar, Annes Dias 285, $90020-090$ Porto Alegre, RS, Brazil. Tel.: +55.51.32148409; Fax:+55.51.32148435. E-mail: severo@santacasa.tche.br, severo@pesquisador.cnpq.br 
OLIVEIRA, F.M.; SEVERO, C.B.; GUAZZELLI, L.S. \& SEVERO, L.C. - Cryptococcus gattii fungemia: report of a case with lung and brain lesions mimicking radiological features of malignancy. Rev. Inst. Med. trop. S. Paulo, 49(4):263-265, 2007.

per cubic millimeter. The CSF cryptococcal antigen titer was 1:4096 with a serum titer of 1:2048. An anti-HIV test (ELISA) was negative. Specimen of blood was obtained for culture with lysis-centrifugation
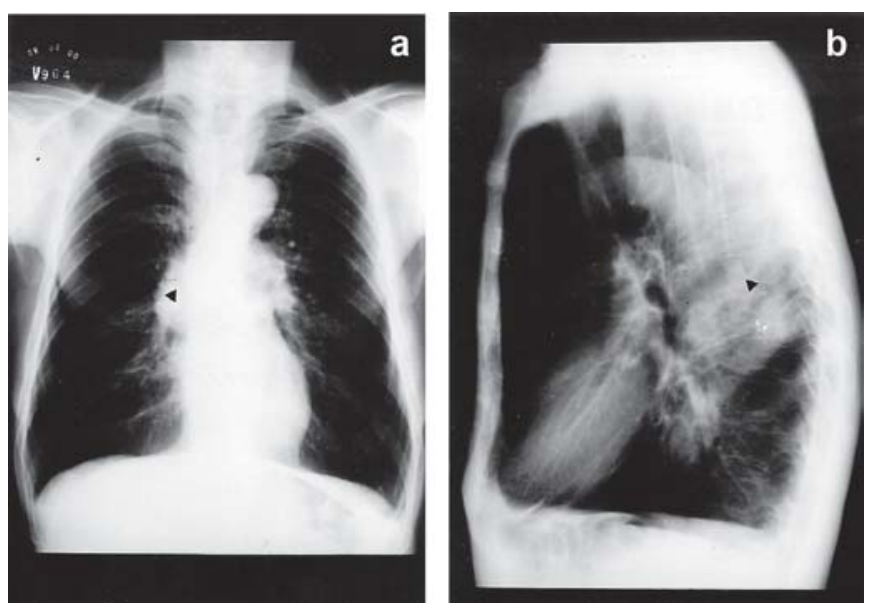

Fig. 1 - Frontal (a) and lateral (b) chest x-rays showing a spherical mass lesion (arrows), 5 $\mathrm{cm}$ in diameter.

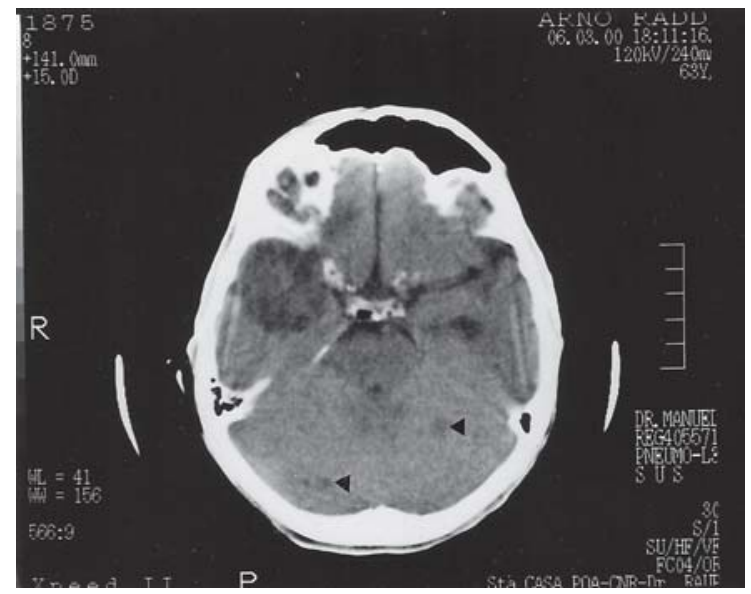

Fig. 2 - Contrast-enhanced axial cranial computed tomographic scan reveals cryptococcoma within the right temporal lobe and multiple nodules (arrows) through the brain parenchyma.

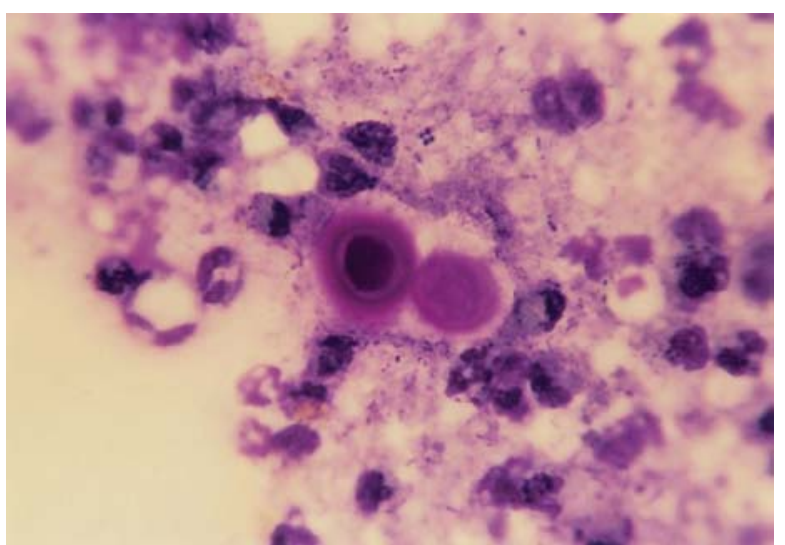

Fig. 3 - Routine MGG stain of bronchoalveolar lavage fluid showing a characteristic budding encapsulated yeast cell of Cryptococcus gattii (x400). technique (Isolator, Wampole Laboratories, Cranbury, $\mathrm{NJ}$ ) and plated on SDA and brain-heart infusion agar (BHI) grew $C$. gattii.

Follow-up cranial CT scan carried out one day later revealed the persistence of the mass lesions and the progression of hydrocephalus. Another chest roentgenogram showed diffuse opacity throughout both lungs with a diffuse brochopneumonic appearance.

Despite the institution of intravenous amphotericin $\mathrm{B}$, the patient continued to deteriorate neurologically and died two days after beginning therapy. The autopsy showed diffuse Cryptococcus pneumonia and multiple intracerebral lesions with numerous fungal cells. Cultures revealed $C$. gattii.

\section{DISCUSSION}

Cryptococcus gattii is emerging as a primary human and animal pathogen. The principal source of the organism is wood debris in hollows, particularly that of eucalyptus ${ }^{8}$ and is prevalent in the tropical and subtropical areas and rare in cold climates ${ }^{5}$. In contrast, C. neoformans is widespread in the environment, especially in areas burdened with bird excreta, and has a worldwide distribution. After gaining entry through the respiratory tract, both have trophism for the central nervous system (CNS); patients infected by $C$. gattii are more likely to evidence focal pulmonary and CNS mass ${ }^{2,7,9}$. Both inhibition of polymorphonuclear leukocyte migration to the site of infection ${ }^{3}$ and inhibition of neutrophil function ${ }^{11}$ by products of $C$. gattii may promote survival of extracellular organisms, and local multiplication to form cryptococcomas.

Infection due to $C$. gattii can pose a diagnostic challenge to clinicians. This case vividly illustrates the fact that, pulmonary cryptococcosis with mass-like lesion with associated cerebral infection, exhibit radiologic features that mimic those of lung cancer metastatic to the CNS. Isolated pulmonary cryptococcosis simulate pulmonary cancer particularly when it appears as an apical mass, including with a typical Pancoast's syndrome ${ }^{6}$. In these cases, cryptococcal antigen testing by latex agglutination, a rapid test with high specificity, would be useful in the differential diagnosis.

Fungemia ${ }^{10}$ and funguria ${ }^{4}$ by $C$. gattii is highly unusual. On the other hand, infections due to $C$. neoformans can be isolated from blood up to $63 \%$ of patients ${ }^{9}$. Positive blood culture is a sign of very poor prognosis and most patients had a high tissue burden of organisms in the lung and $\mathrm{CNS}^{1}$, like our patient.

In summary, $C$. gattii must be included in the differential diagnosis of pulmonary and brain masses. Furthermore, with fungal cultures, smears, and serologic test systemic cryptococcosis will be diagnosed sooner, leading to earlier treatment which may be life-saving.

\section{RESUMO}

Fungemia por Cryptococcus gattii: relato de um caso com lesões cerebrais e pulmonares nos achados radiológicos mimetizando câncer

Homem branco de 64 anos, aparentemente imunocompetente, desenvolveu lesões pulmonares e cerebrais por criptococose dissemina- 
OLIVEIRA, F.M.; SEVERO, C.B.; GUAZZELLI, L.S. \& SEVERO, L.C. - Cryptococcus gattii fungemia: report of a case with lung and brain lesions mimicking radiological features of malignancy. Rev. Inst. Med. trop. S. Paulo, 49(4):263-265, 2007.

da. Os achados radiológicos foram similares àqueles encontrados em pacientes com câncer de pulmão e metástase no sistema nervoso central. C. gattii foi isolado de cultivos de lavado broncoalveolar, biópsia cerebral e sangue. O mesmo fungo foi encontrado em fragmentos pulmonares e cerebrais obtidos da autópsia. Testes de antígeno no soro e no líquido cefalorraquidiano foram diagnóstico no nosso caso e devem ser incluídos na avaliação diagnóstica de lesões pulmonares e cerebrais indefinidas. Pesquisa na literatura mostrou poucos relatos de fungemia por esta espécie de Cryptococcus, contrastando com $C$. neoformans.

\section{REFERENCES}

1. CASADEVALL, A. \& PERFECT, J.R. - Human cryptococcosis. In: CASADEVALL, A. \& PERFECT, J.R. Cryptococcus neoformans. Washington, American Society for Microbiology, 1998. p. 407-456.

2. CHEN, S.; SORRELL, T.; NIMMO, G. et al. - Epidemiology and host-and varietydependent characteristics of infection due to Cryptococcus neoformans in Australia and New Zealand. Australasian Cryptococcal Study Group. Clin. infect. Dis., 31: 499-508, 2000.

3. DONG, Z.M. \& MURPHY, J.W. - Effects of the two varieties of Cryptococcus neoformans cells and culture filtrate antigens on neutrophil locomotion. Infect. Immun., 63: 2632-2644, 1995.

04. IGREJA, R.P.; LAZÉRA, M.S.; WANKE, B. et al. - Molecular epidemiology of Cryptococcus neoformans isolates from AIDS patients of the Brazilian city, Rio de Janeiro. Med. Mycol., 42: 229-238, 2004.
5. KIDD, S.E.; HAGEN, F.; TSCHARKE, R.L. et al. - A rare genotype of Cryptococcus gattii caused the cryptococcosis outbreak on Vancouver Island (British Columbia, Canada). Proc. nat. Acad. Sci. (Wash.), 101: 17258-17263, 2004.

6. MITCHELL, D.H. \& SORRELL, T.C. - Pancoast's syndrome due to pulmonary infection with Cryptococcus neoformans variety gattii. Clin. infect. Dis., 14: 1142-1144, 1992.

7. MITCHELL, D.H.; SORRELL, T.C.; ALLWORTH, A.M. et al. - Cryptococcal disease of the CNS in immunocompetent hosts: influence of cryptococcal variety on clinical manisfestations and outcome. Clin. infect. Dis., 20: 611-616, 1995.

8. SORRELL, T.C. - Cryptococcus neoformans variety gattii. Med. Mycol., 39: 155-168, 2001.

9. SPEED, B. \& DUNT, D. - Clinical and host differences between infections with the two varieties of Cryptococcus neoformans. Clin. infect. Dis., 21: 28-34, 1995.

10. ST-GERMAIN, G.; NOEL, G. \& KWON-CHUNG, K.J. - Disseminated cryptococcosis due to Cryptococcus neoformans variety gattii in a Canadian patient with AIDS. Europ. J. clin. Microbiol. infect. Dis., 7: 587-588, 1988.

11. WRIGHT, L.; BUBB, W.; DAVIDSON, J. et al. - Metabolites released by Cryptococcus neoformans var. neoformans and var. gattii differentially affect human neutrophi function. Microbes Infect., 4: 1427-1438, 2002.

Received: 31 August 2006

Accepted: 9 January 2007 